SF 287

.S67 
or

10

$10^{3}$

\% स : :

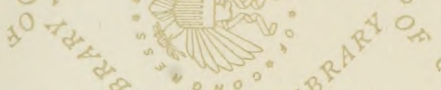

कर느:

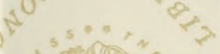

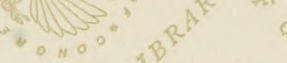

-

t.

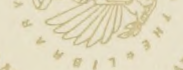

S 5 a<smiles>[CH+]1CC1</smiles>

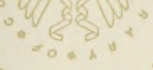

$s_{1}$

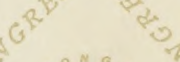
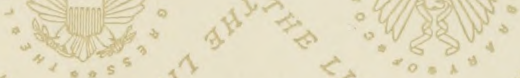

Pe $c^{0}$

$+0^{\circ}$

0

सह के

ins

ants:

(o)

$8^{2}$

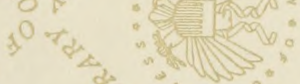

$\rightarrow \infty$

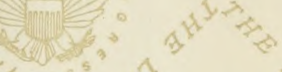

$10^{\circ}$ ?

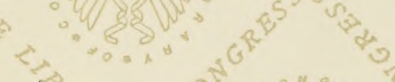

स. $\sin ^{4}$

189

$P \neq 0.0$

$s^{2}$<smiles></smiles><smiles>[CH]</smiles>
$*$ है sod $\leqslant<$ 3. $\operatorname{Qp}_{\vec{P}}$ $\left.\therefore 88^{\circ}\right)^{\circ}=$ $\mathrm{C}^{\circ} 0^{\prime \prime a}=2$ S

, n

8

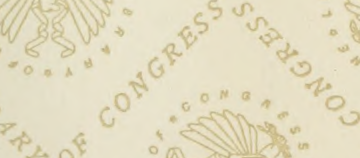<smiles></smiles>

(a)

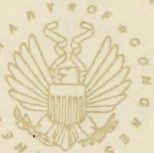

P
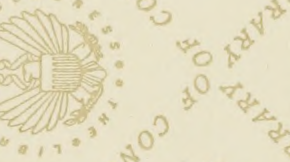

${ }_{2}^{3}$

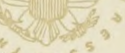

$40.5^{5} \wedge$

(3)

4 बु 






\section{,}




$$
2^{10}
$$





$$
\text { . }
$$




$$
\mathbb{A}
$$


COPRHIITE, 


\title{
Character Building
}

\section{( $\mathrm{OR}$}

What I Know About Breaking and Training Colts and * Horses *

\author{
BY \\ EUGENE SNOW, \\ CLOVERLAND STOCK FARM, \\ KNOXBORO, N. Y.
}

Copyright, I905, by Eugene Snow. 


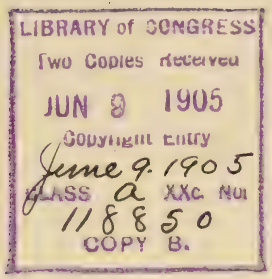




\section{What I Know About Breaking and Training Colts and Horses}

When I say that I have spent thirty years of my life on a stock farm as a breeder and owner of race, road and carriage horses, it does not mean that the time has been wholly spent in supervising or directing some one else to do the work, but that I have at all times had a practical hold of the business, working out its problems and bringing them to a successful issue, with my own hands breaking, training and otherwise educating and racing the products of the farm. I beliere I am the only man living or dead who has raced horses, of his own breeding and development, for twenty-five consecutive years. Having 110 other means of a livelihood, it may strike the reader that this could not have been done without a certain amount of success. For the 
benefit of any who may conclude that I am in any sense of the term a "has-been" and too old to do anything but write memoirs, I will say that I am still on the meridian line of life and am neither going nor dying out of the business that has proven the source of very much pleasure and not a little profit. As evidence that I am abreast of the times, I offer "Happy Bill," thought by many to be the greatest two-year-old trotter that has yet appeared. He was exhibited at the Oneida County and New York State Fairs last fall, stepping a half in $\mathrm{I}: 06$, a quarter in $3 \mathrm{I} / 2$ and an eighth in ${ }_{5} 5$ seconds, officially timed in the presence of thousands of spectators.

While the practical ideas I have formulated between the covers of this little book are the results of a long and varied experience with high-bred, and many times very nervous animals, I do not say that they are wholly the product of my own brain. They are none the less valuable, however, and are intended more 
particularly for farmers, and others who may breed one or two animals each year and have not made the training of colts a study. They do not throw any light on the treatment of horses which have acquired vicious or ugly habits, but are a sure preventive of such habits, as my record of never having produced a vicious horse will show.

By way of opening I will make three suggestions :

Ist. Break the colt when he is young, the winter he is coming two.

2nd. Throw away the whip if you cannot use it with discretion.

3rd. If you have an ungovernable temper yourself don't try. 


\section{CHARACTER BUILDING}

The weanling should be in a large box stall or shed when he takes his first lesson. $\mathrm{W}^{\top}$ e find him usually in a semi-wild condition in absolute fear of the being who now appears before him as a would-be teacher, and in some instances ready to fight him. Such a colt was "Happy Bill"' when I closed the door between him and the only friend he had known up to that time-his mother. He faced me with defiance and fear plainly written on his countenance. I doubt if I had men enough in my employ to, with safety for themselves and the colt, force the halter upon him; but in less than three minutes I had it securely on his head and he had scarcely moved from his tracks. It was done by simply hanging a common rope halter on the end of a twelvefoot pole. On the side of the pole, very near to the top end, had been driven two twelve penny nails diagonally, one towards the top, 
the other towards the bottom of the pole so that the heads of the nails would come very nearly, if not quite together for the purpose of holding and spreading the head-piece of the halter, thus allowing for a large opening at the noose end. Carefully raising the halter so that his nose was well into the noose I turned the pole, allowing the halter to drop into position on his head. I then picked up the lead rope and proceeded with his lesson, the first principal of which consisted in teaching him that instead of being an object to fear, I was his friend, but at the same time his master. I could have taught him to lead in ten minutes, but I stayed with him an hour, petted him and talked the same language that I would to a little child whose confidence and good will I wished to gain. I said the same words and offered my caresses many times before they were accepted and understood, but since that time he has rewarded me a hundred fold for the little time and patience I gave to him in that first lesson. That lesson was 
really the establishment of a character, which to-day is a model of all that is good in a horse. While I could describe many similar instances in my experience with colts at this age which might be interesting and instructive and tend to show the great value of kindness I will mention but one more.

Being laid up with a badly bruised ankle at a iime when the weaning of the sucklings was necessary, I gave instructions to my men to separate the brood mares from their colts and give them their first lesson in the halter. I charged them under no circumstances to resort to severe measures without first consulting me and carefully explained my methods. They got along pretty well with all but one, and he was by far the best colt in the bunch, both in breeding and individuality. They said to me, "That colt is the deril-he will kick, bite and strike. IVe got the halter on but cannot get it off."' Thereupon I sent a girl twenty years of age, whose love for horses is only ex- 
ceeded by her desire for their humane treatment to interview this terror. I do not exaggerate when I say that in twenty minutes from the time she entered the stable she was leading him in the yard with her arm about his neck. It was simply fear, not malice, as demonstrated by a woman, that prompted him to do wrong. Be kind, but firm, and always the master.

When for the first time the colt feels the halter and realizes that there is a limit beyond which he cannot go, if he is a real good one he will resent it hard. Keep his head towards you, loosening on the lead rope only to save a fall or collision, and do not ask him to come to you until you have first been to him and convinced him you are his friend. Then teach him to lead by pulling him towards you one way and then the other (not in a straight line at first). Always when he comes, whether forced or otherwise, caress and reward him with a lump of sugar or salt, or a 
piece of an apple you will have in your pocket. They are the corner stones in character building.

But there is a line or limit even to kindness beyond which you cannot go. Do not at any time of life allow him to become a "pet" in the sense that he will not respect your word, or command, or take liberties your judgment tells you are wrong. "Familiarity breeds contempt," they say, in the human family, and it is no less true with horses. Punish him if he persists, but in a way that he will understand and that will frighten more than injure him. Continue these lessons every day for a week, and if your time is limited once or twice a week during the following winter months. After the first lesson you will find it a pleasure, as he will love the sound of your roice and your footsteps will be music to his ears. Then, if you have the fear of God, or the love of a little child in your heart you will not abuse the weanling and his future will be safe in your hands. 
Having laid the foundation, the work should be discontinued and the colt turned out to grass the following summer. I have, however, kept them in the stable and handled them successfully at this age when I had a special object in view, as in the case of "Queen Bird," 2:25 at two years. Wishing to establish the value of her sire as an early speed progenitor, I selected this filly and trained her for that purpose, and how I succeeded her public exhibition quarter of a mile as a yearling in 33 seconds will show.

Experience has taught me that at the expiration of the yearling's season's run to pasture in his two-year-old form, an age at which although still a colt, he is beginning to show some of the elements of a horse, is the time of all others when by nature he is more susceptible to influence, either for good or evil, than any time during his whole existence. Therefore, I cannot put in too strong language the importance of continuing the 
lessons with even more thoughtful, judicious and patient care than when they were begun.

The following example will serve to illustrate the effects of injudicious handling at this age: When quite a young man, and young in the business, I bred and owned a little chunky, low-headed, Roman-nosed brown filly. At the time of which I write she was two years old and a cheaper looking colt it would be hard to imagine. When I looked her over and contemplated the prospects for the future of the breeding industry, with a barn full of her kind in a rising feed market, my aspirations took a drop that came near upsetting all my plans. Although not ugly or vicious, she was loaded to the muzzle with grit and determination. My patience left me early in the game and the little judgment I started in with was soon scattered all over the farm, and finally landed horse, trainer and sleigh in a general nix-up in a large snowbank. Disentangling the outfit as best I could, I led my 
pupil to the stable with the promise that I would, at some future time, give her the treatment I felt sure she needed, and that promise I kept, laboring all day with two assistants in a vain effort to make her draw an empty cart. She won at the finish, and a cheaper looking lot of men never left a battle field than followed the little brown mare to her stable that night. Believing her to be worthless I offered her as a Christmas gift to any one who would lead her off the farm. As I could find no takers she remained, and one year later I tried again on the principles that are in force at Cloverland to-day, and won. She proved herself not only extremely fast, but the greatest road mare I have ever known, and dereloped qualities which I believed must be perpetuated if I were to succeed in the business. She has produced Timepiece, 2:10 1/4, the sum of whose winnings and sale, and sale of others of her produce amounts to over $\$ 9$, 000 . She has now on the farm two full brothers to Timepiece, 2:101/4, for one of which I have re- 
fused $\$ 2,000$. A fair Christmas present she was. Although I saved her from the ruin I so nearly wrought, the thought of it has never given me any pleasure, and I publish it with no degree of pride, but only as an example in the hope that it may serve as a guide to some man, as inexperienced as the writer was at that time, by which he can avoid such mistakes.

Never put a bit into a colt's mouth until you have first examined and prepared the teeth to receive it. In front of the molars you are sure to find little supernumerary growths, called wolf teeth. They are said to interfere with the eye by exerting an influence on the opthalmic division of the nerve. Whether that is true or not I cannot say, but it is a dead sure thing they should come out and the rough edges of the outside of the upper teeth (the molars) smoothed down before attempting the process of "bitting." Whatever success you may have had may count for 
nothing by injudicious treatment of the colt's mouth at this time.

While it was my intention in writing this book not to in any way connect it with the reterinary branch of the horse business, the process of preparing the colt's mouth is so simple, and yet so vitally important, that to pass it by without a word in explanation would not only be unfair to the student, but an injustice to the animals themselves. But before doing so I will state a circumstance directly bearing on this branch of the colt's education that has firmly planted itself in my memory.

A trainer of some note in the conntry where he lived was endearoring to break a highkeyed, mettlesome, three-year-old filly. When I first saw them the colt was hitched to a cart with the trainer on the seat. She had backed the wheels of the cart against a barn, and with her feet firmly planted in the ground, 


\section{8}

she steadfastly refused to budge. Such a pounding as that filly received it beats my pen to describe. With every vestige of reason gone, that man was a revelation to his andience, some of whom were ladies. During a lull in the storm, at the risk of getting into trouble myself, I stepped to the colt's head and said to the trainer, "If you will come here, I believe I can show you why your colt refuses to go." Thereupon, I opened her mouth and displayed two ugly wounds on either side of her cheeks, an inch in length, and cut almost through to the skin. I also showed him the wolf teeth with points as sharp as needles, and the rough, uneven edges of the molars. Is it any wonder she preferred the whipping? Now, in his normal condition, this trainer was far from being a brute in disposition. On the contrary, he was amiable and kind, and could be depended on always to champion and defend the cause of any honest man or horse in trouble. IT'ithout a word he unhitched the filly and led her to the stable, came back to the hitching floor and 
sat down on a box, and for awhile rested his head on his hands, and I knew he realized his mistake and was suffering all he deserved to suffer. With his head still on his hands he made this remark: "What would you do if you had made such a show of yourself as I have to-day ?" I answered: "That having been there, or nearly there myself, I thought I knew a little how he felt, that such education came high in loss of self-respect, but I believed in his case it was worth the price; and I will add, that he finished that colt's education in all the essential qualities of a race horse in a way that made her a model of good behavior. Her affection and confidence in him during the nervous excitement preceding her races was almost pathetic.

I will say to any man who attempts the bitting or breaking of a colt to drive without first attending to his mouth, you are not only taking long chances on the "physical culture" part of your anatomy, but also on destroying 
the worth of an animal you aim to make valuable for your own, or somebody else's use.

The above is not an isolated case by any means, but one of many, by which to-day incompetent, unstudied and careless handlers are ruining the character and disposition of otherwise meritorious animals. You may not be in the business of breaking and handling colts, hence the illustration is not applicable; but whatever your occupation in life, if you have been blessed in receiving and entrusted with the care of one of these noblest of all animals, of any age or condition, either for profit or pleasure, be merciful in a measure that you may sometime need it meted out to you, and in no better way can you show the attribute of mercy, than by thoughtful, judicious care of the horse's mouth.

Your outfit as an amateur veterinary dentist will cost you not to exceed three dollars, possibly less, and should consist of an ordinary 
pair of forceps, (such as dentists use in extracting human teeth will (lo), and a common float or file, made for the purpose of correcting faulty growths on the teeth of horses. The float will cost a dollar. A pair of forceps can generally be procured from your dentist at a nominal price, which, while they may be a back number with him and have been discarded for more modern instruments, will answer every requirenent in your case. The extracting of wolf teeth requires no particular anount of skill. Only secure a good hold and leep it with a rigid hand, but with a flexible wrist to allow your hand to adjust itself to every morement of the colt's mouth. Do not hurry, but wait until he has become quiet, before you attempt to take out the tooth. While it is more skillful and workmanlike to extract the entire tooth, I have never known any harm to come from a broken one, the root of which was left in the horse's mouth. The wolf teeth having been attended to, run your fingers along the outer 
edges of the molars. If you find them rough, sharp and uneven, then you certainly have business with the float. Stand in front of your subject, and with your left hand on his nose carefully insert the file into his mouth along the line of the trouble on the right side. Take plenty of time and do not hurt him, and he will soon learn that he has nothing to fear and will allow you even in the clumsy way of a beginner to finish your work without a protest. Holding your float on a line level with the teeth, with your right hand pass it a few times along the rough places. Then remove the instrument, examine your work, and stop when you find them comparatively smooth and free from any projections which you think would injure the colt's cheek in being forced against it by the working of the bit. To successfully and easily accomplish the same good results on the opposite or left sicle of the mouth, standing as you are supposed to be in front of and facing your patient, with your left hand on his nose, move your body to the 


\section{3}

left side of his head, allowing your left hand to go under his lower jaw and around until you can get hold of his nose on the opposite side, then you will have free play for your right hand to work the float over the left arm and into the horse's mouth, while your left hand holds his head steady and in position. The matured horse very often suffers from sharp projecting teeth, and it is very common in old horses from the wearing down of the teeth in an nneven manner. They will be sharp on the inner edges of the lower jaw, and the outer edges of the upper jaw, which may be from faulty formation. In such cases the animal has difficulty in eating, often grinding and ejecting the food. Often horses carry their heads to one side when driving from this cause. If their teeth are sharp on the inside they lacerate the tongue, if on the outside as I have already described, they lacerate the cheek. As the processis similar, I shall not give in detail the treatment of the lower molars, believing that when you get to them 
your judgment will direct you how to continue the work.

If you have followed the directions, you should now have a model pupil with which to continue the important work that is to follow, which consists in teaching him to drive.

First hitch him with a strong halter to something he will not break, or pull out if he should try; then with the saddle part of your harness, with breeching attachment, rub him all over and under his body, occasionally allowing him to smell of it until he is familiar with and not afraid of any part of it, then place it in position. Do the same with headstall and collar. You should do this work alone, unaided by any assistant, as you will need his undivided attention. The lines should not be less than thirty feet in length - a small rope will do. Run them through the thill holders in the harness to the bit, (thill holder girt should be buckled to hold them down 
and in position). Do not at first attempt to raise his head abore its natural position by checking. Now take hold of your lines, which you are supposed to be able to skilfully pay out or take in as necessity may require. Give him his head and allow him to go out of the stable or barn. If he goes out on a run, which he is very apt to do, give him rope, and as soon as you can, turn him from a straight line into a circle. Handle his mouth with care, always with a light hold of the reins, so that if he starts up suddenly, instead of snul)bing him you can allow them to slip through your hands so that you can rate your speed and the colt's, carefully restraining him.

Perhaps I can in 110 better way explain or illustrate the value of proper handling, or the bad effects of improper handling of the colt, in these first lessons in the harness than by the following example:

While driving along at a smart trot, one fine Spring day, late in the afternoon, through 
a not over-populated section of the country, from the midst of a pleasant train of thoughts, I was startled by these words: "Hello, there, Captain! Look me up and tell me where I am.' The voice seemed at first to issue from the bushes that lined the road, but a second and more careful inspection showed me not far away in a lot a man about thirty years of age, and what should have been a handsome chestnut filly. ( The colt I learned was three years old.) The man was stripped to his pants and shirt, and hatless, stood holding a pair of lines in one hand and the remnant of a rawhide whip in the other. The lines were an ordinary pair, of regulation length, reaching about eight feet back of the colt and buckled together at the end. Stopping my horse and taking in the situation, I said to the trainer: "Would you like to send any word home?"' He sat down on the ground and laughed. The drollery of the thing struck me and I joined in. "Yes," he said, "tell them to send out a team of oxen and 
a stoneboat." With some questioning I found the colt had started out very well. It was her first lesson in the harness, but being quick, active and resolute, as I had guessed, she was away, and to the limit of the short lines before her trainer could get under headway. When he did get in motion the colt was stepping so fast that he had to pull her up with a sudden jerk to stop her. After repeating this performance several times she finally refused to go without the whip, and when I found them she would not go with it, and he had given it to her without stint. He said to me, "'This mare is the worst I ever saw. I will have to pull off her harmess and let her go, as she will neither lead nor drive. Do you know anything about handling this kind ?"' I replied that I believed I did, and that if he would put the halter on my horse that he would find in the carriage and lead him along, although I might fail, I told him I would make an effort to drive his filly home, which was about a mile distant in the direction 
I was going. "We11, go ahead, Mister," he said, "You are the party I was looking for." Thereupon I removed the lines from my harness and connected them with those already on the colt, adjusted the bit, took off the crupper, which from continual jerking of her head against the check-rein had chafed her to a bleeding condition. I then threw off the check, and spent a little time in talking to, and getting acquainted with her. Finally I asked her to go, at the same time I pushed her two or three feet to one side. This was a new deal and she appeared to be surprised. I repeated this treatment several times. At last she plunged forward on a run, but I was ready and ran with her. Gradually allowing the lines to slip through my hands, at the same time I pulled gently on one of them. Before she got to the limit of my lines and speed I had her going in a circle, and from a run she slowed to a trot, and soon to a walk, and she went on at that gait until I said Whoa! and stopped her. I then went to her head and re- 
peated the old words of kindness, and while it may have been my imagination, I shall always think the look she gare me was one of gratitude. I then drove her to the stable without further trouble, and after receiving a profusion of thanks from her owner, continued on my way.

The preliminary lessons with the long lines offer great opportunities for the advancement of your pupil and of placing some of the main stays in his character. Be thorough and persistent, and teach him to respond readily to every touch of the line, at the same time be careful about working him too much in one lesson. When you want him to stop, say Whoa! and stop him. Do not repeat the command. Once is better than twice, and in repeating the word a dozen times, as you will generally hear, it fails entirely in significance to the colt. Whenever he obeys the word, whether forced or otherwise, reward him in the old way with kind words. Go to him and 
adjust some part of the harness, giving the impression that you had a purpose in stopping him. Do not allow him to start until you tell him he can go. Teach him that at all times it is your will, not his, which must be obeyed.

The importance of the above lesson well implanted in the colt's memory will be better understood and appreciated when I say that not once, but very many times, has the writer during his varied career with horses escaped serious injury, and he believes that he owes his life to-day to the thorough instruction his colts have received in this branch of their education. The following examples, happening as they did in public, will no doubt be recognized in this connection, although times and places are not given. They will serve to show the inestimable value in times of peril and danger of the firm establishment of this early and simple lesson on the bed-rock of the colt's memory.

It happened on a half-mile track in a neighboring town at the finish of a workout mile. 
Although the mile was slow, the accident came at the finish, when one of the most resolute, determined and high-strung horses I have ever driven was at the very limit of his speed, which was not slower than a 2:10 gait. A sound like the rattling of a bolt caught my ear, and before I could speak I was down with a smashed sulky wheel, and braces. The professional will tell you that any accident by which the wheels of the sulky should come off or go down, would find the frame resting for support on the hind legs of the animal he was driving, the driver on the seat with his legs and feet elevated to an angle of 45 degrees or more. He will also tell you that there is not one horse in ten thousand, that under the same conditions would not either attempt to run away or kick himself free. The fate of a driver in such a "mix-up," with a horse disposed to be mean, can be better imagined than described. Although but one of my wheels was down it left me in a position even more precarious than that I have described. Had 
he kicked I was a mark he could not miss. He was terribly frightened, and when I saw the blood gushing from a long deep wound in his ankle, with one of the steel braces still boring it, I do not hesitate to say I trembled with fear lest he should not heed my voice, and the old lessons taught him in his earlier days would not avail me at this critical time. But like the noble animal he was then and is today, he heard and obeyed, and almost supporting the sulky frame with the weight of the driver on his bruised and bleeding ankle, he came to a stop within thirty paces and waited until I could get off. Do not think that in unlitching and freeing him from the wreck I failed in telling him what he was, and I have never doubted that he understood and appreciated every word I said.

Another time in a race, from the force of a collision and fall of the horse, I was thrown violently to the ground. Getting up in a somewhat dazed condition, I found $11 \mathrm{y}$ horse stand- 


\section{3}

ing with one of his fore feet caught in the wheel of a smashed sulky in front of him, the driver and horse to which it belonged being spread out on the ground, he tried, but could not loosen his foot, and with $n o$ hand to restrain him, he was ready to plunge forward into the wreck ahead. With his own sulky broken and gouging him, his foot in a sling, is it any wonder he was frightened; but I spoke to him in time, in a language and tones he understood, and that he had been taught to obey, and he responded, and waited with scarcely a struggle until I could come to his assistance.

We will suppose your pupil to have been driven every day for two weeks with the lines, and if you have done your work well, and he is a fairly intelligent scholar, he should now be ready to take the last lesson in the course, which consists in teaching him to draw some kind of a vehicle. For a long time, during my early days in the business, I allowed my men and did myself give this lesson, by hitching 
directly to a cart or sleigh, but never with success. It is true we "broke" them, but many times at the expense not only of property, but of some of the best qualities in both horse and man. To obviate trouble and simplify this part of the work, I designed "The Dummie" and put it together in about 20 minutes. This - is the most valuable accessory to a trainer's outfit for breaking and educating colts I have ever known. To manufacture this simple device requires two twelve foot poles (hickory is the best), three inches in diameter at the butt end, tapering to one inch at the top end. The poles should be stayed and braced three feet apart at the butt, running like a pair of ordinary shafts to within is inches of each other at the front end. The braces at the butt can extend over about three feet of the poles. To some part of the bracing, attach a strap or small rope with snap in the end with which to connect the tugs extending from the breast collar on the colt. Bevel the under side of the poles at the butt end to allow of their easier 
manipulation in all the different turns it is sure to take. If you have been thorough in your instruction up to this time, your pupil should be well mannered and disposed to obey; not afraid of you, but confident and trustful, ready to stop and start only at your command. With the "Dummie," as with the harness, hold it up for him to look at and smell of. Drop it on the barn floor, not too close to him at first, but where he can see and hear, all the time coming nearer as you see he is getting accustomed to the sounds. His past experience and acquaintance has been such that he thinks he has nothing to fear from you, no matter what you show, and he will very soon allow you to drop it very near him and make all the noise you wish, and will stand quietly while you hitch him to the "DDmmie." I wish to emphasize in this connection the importance in hitching a colt (even after you have him well broken), of always having hold of the lines. Never allow the lines out of your hand or off your arm from the time you take 
them down, after putting on the harness, until you have him unhitched and clear from whatever vehicle you may have been driving to.

A wealthy man, a breeder in a small way, from the northern part of the State, drove into my barn one day, and among other things, he said, "Have you a system for the breaking and handling of colts and horses? If you have, and can show that it has any practical value, I will pay you well for your trouble, and any ideas I may get in the demonstration.'” And then for an hour he entertained and amused me with a graphic discription of his experience with different trainers, and one in particular, whose work he described, I will give here as nearly as I can, in the words in which it was related. As it represents the other side of the picture or theory of handling horses, I will leave it to the reader to determine their comparative value:

"He was a typical cowboy in appearance, but as he came well recommended from his for- 
mer employer, I felt sure that I had the real article. I endeavored to draw him out several times in explanation of his methods, etc., of breaking colts and handling them for speed, but as he did not appear disposed to talk on the subject, I placed him as one who could put his ideas into practice better than words. My confidence was such that it was six months from the time he began work before I had an opportunity of witnessing his unexplainable methods of colt breaking. With the help of two assistants, he was hitching to a cart a large, powerful and high bred three year old filly, one that, he told me, had bothered some at first, but was improving very fast, and would soon do to take into town for the owner's pleasure driving, and he also stated that he believed her to be a race horse. They hitched her, facing the doors opening to a sharp descent, over a bridge, through a driveway, thence with a sharp turn to a gate into the highway. When all was ready, the order was given and the mare released. At first I 
38

thought she would not go at all; she reared and swerved first to one side of the barn and then the other. Believing that 'self-preservation is the first law of nature,' I ' ducked' for the yard, not any too soon, and I then beheld such an exhibition of wild driving as would put to shame the most daring performer in Buffalo Bill's aggregation. Going out of the barn on a run, with a succession of jumps, plunges and dives, he cleared all the openings, and on one wheel of the cart made the turn for the highway and disappeared from sight on a run, exhibiting all the race horse qualities he had claimed. As the smoke and dust cleared away, I said to the assistant, ' That mare isn't what you would call a real good behaved one, is she?' He replied, 'She is acting good, now ; you should have seen her the first time she was hitched.' I said to him, 'William, this farm covers a territory of about three hundred acres of ground; it has been in my family for more than a hundred years; it is a part of me, and having traveled every foot 
of it by daylight, by moonlight, and by no light at all, I know it as I know myself. Let me say to you, my boy, if that first lesson beats the one now in the works, I am not sorry that I did not see it. I feel that I have had a narrow escape, and knowing the place as I do, I cannot think of a tree within its boundaries in which I would feel safe from the Professor and his pupils.' I grow chilly when I think of meeting him on my return, although I think he will not be back to-night; but in this I was mistaken, as I met my trainer, or a man I took to be him, with a mask of dust and blood on his face, leading a lame horse, and further along I found the cart a total wreck, by the side of the road, near to where he had collided with a loaded team. Thankful it was no worse, I went to my home that night firmly resolved to either abandon the business of breeding entirely, or give it some personal attention."

The above is possibly an extreme case, but it was interesting in the narrative, as it para- 
lelled scenes that the writer has many times witnessed during his experience in the business.

An object appearing suddenly to a colt is generally what frightens him the most. Be careful about using the whip at such times, it will only add to the trouble. Whenever he sees anything of which he is afraid, drive him slowly and carefully, but firmly toward the object and show him he has nothing to fear.

If you aim to raise a trotter and race horse, breed the best mare you own or can afford to buy, a mare great as an individual and by inheritance, to some stallion that is a race horse himself, and has demonstrated his value as a sire of race horses. Break the offspring according to the foregoing rules. When you have him well broken, put on him a pair of quarter boots and scalpers; the latter by all means. They are more essential in gaiting a colt than any horse boot known to the business. Thousands of "hitchers" have been 
started by incompetent handlers, too lazy or ignorant to suitably protect the colt at the very spot where the gaiting process should begin. Adjust the harness as you do your clothes, so that it will fit and be comfortable. It is important to see that it does not chafe or irritate him. 'This quality to feel for your pupil is not made, but born in a horseman. Adjust the bit in the same way. Never use any devise whatever that is calculated to punish the colt through his mouth without you are looking for and inviting trouble. In developing and educating for speed, ask the colt to go just as fast as he can a few times for short distances every time you hitch him and can find a smooth place. Do not confine this work to the track or to a perfectly level spot. Avoid everything that may become monotonous or tiresome to your pupil. Study him and his characteristics, he may need a little more or a little less work than you are giving. Be his true and loyal friend, and always the teacher whose will is law. If you find the colt in a 
dull or sour condition, give him his regular work without any attempt at speed. Encourage him always to a better effort. If he tries and fails, or makes a mistake, talk to him about it in a calm and confident tone, and don't get it into your head that he cannot understand you. This is one of the greatest errors young men make in not treating their pupils as being able to understand the English language. If he tries and succeeds, the colt knows it himself and does not need your counsel. If he is the kind that wont try, then make him. Do not lose your patience and twitch and yank him, no matter what the provocation, and be careful of the whip; it is a dangerous implement in the hands of a quick tempered man. The writer makes no claim to angelic qualities or disposition. He recalls a time when he drove a four year old filly straight to the barn, and without unhitching threw down the lines, went away and stayed until he felt he could control himself, then went back, sat down and studied for half an 
hour, found the trouble and successfully continued her training. Remember, that the race horse does not live of any age that is every day alike, so rate your treatment of the con $T$ accordingly. When your pupil begins to show that he understands what you want of him, and has the ability to comply, carefully watch him, for as he increases his speed he may strike himself in some spot which must be cared for at once. From this stage the improvement should be rapid, and just how much speed and race horse qualities the colt will derelop depends not wholly, but very much on the patience, perseverance and judgment of his trainer. In all cases time will be saved and ultimate success more assured, by removing the shoes from the two or three year old and allowing him a run to grass in a paddock during the month of June, where the soil is of a soft, loamy nature. In continuance of the training from this stage, supposing your pupil to have the required amount of speed, if le wins any money it will be necessary for 
him to carry that speed a mile. With this in view, I have trained my colts to go away, or score just as fast as they are capable for the first sixteenth, then slowing them to an easy jog, and finishing the last sixteenth to the very limit of their speed; gradually and systematically increasing the distance of speed at both ends, thus lessening the intervening space according to the colt's condition as he may attain strength to perform. This is a delicate task for even the most experienced men in the business, and calls for all the qualities you possess.

REMEMIBER, the colt's mouth, as a rule, is what you make it. Teach him to drive with a light hand. No puller, in this age of extreme speed, will do.

I will give in this connection one more example, or illustration, which may serve to illumine the lettering on the guide-board I would erect, pointing out the road to success, through a closer bond of sympathy and under- 
standing between horse and man. Without fear of contradiction, where the horse is known, I will say that no greater, better behaved, gamer, or more consistent race horse ever lived than Timepiece, 2: IO I/t. Beginning his racing career as a two year old, he was out for the money each following year for seven continuous years, winning the most, and fighting all his races from early Spring to the last days of October.

The writer makes no claims to any credit for what honors Timepiece may have achieved as a race horse. At the time of which I write I had in my employ a young man who, had he seen fit to continue in the business, and give it his thoughtful care and attention, had qualities which would have placed him in the very front rank of his profession. Timepiece owes it to this young man's patience, perseverence and good judgment, that he was not discarded as worthless for any purpose whatever. Overflowing with grit, determination and speed, at 


\section{$4 \dot{6}$}

the age of three years this colt passed through a stage in his career which was critical in the extreme; although it was only of a few days duration, it marked the junction of the roads that lead to failure or success, and proved an epoch in the career of both horse and the coolheaded boy who, with unerring hand guided him straight, and brought out the very best qualities in his nature. For some unaccountable reason this colt one day deliberately refused to score, or speed towards the starting point, where his miles should begin. He would shake his head, swerve first to one side of the track and then the other, finally going forward at a gait that would puzzle a man more capable than the author of this book to describe. Perhaps the nearest to a description of this newly acquired gait would be to repeat what the man said to a local judge, before whom he had been arraigned in court on a charge of intoxication and unlawfully running his horse through the streets. When asked what he had to say in his defense, he replied, 
"Judge, did you think that horse of mine was running, if so you are mistaken: I live near to Cloverland Stock Farm, and can tell you that is a new gait we are teaching onr colts, and we call it 'Hoppy-to-pace.' ', In telling me the story, the judge said he never knew how he preserved the dignity of his office. Well, "Hoppy-to-pace" it was for Timepiece until I turned array in disgust, after a two weeks' trial of patience, which I beliered should be the limit, and so expressed myself at the time, recommending severe measures: I was met with the plea to allow the work to continue, with the responsibility for good or evil to rest with the trainer; and how he succeeded, 'Timepiece's record of good behavior during his seren years of racing will show.

I would say in conclusion, that animals, like men, differ very much in disposition as well as in intelligence, and in their early education and discipline, as with human beings, that system should prevail by which you can in 


\section{8}

the simplest manner reach the understanding, not of one, but any of the various temperaments of the breed. While there may be other methods equally as good for the handling and training of colts, there are none more simple and sure of success for the amateur than those outlined between the covers of this little book. In such a degree as colts are unlike in disposition and intelligence, so will they differ in their manner of receiving their instructions, and no rule but that of common sense can be laid down for the man who attempts their education.

\section{$34.77=61$ Lot-19}




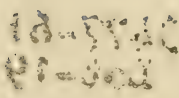




IJUN 9,8905

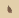








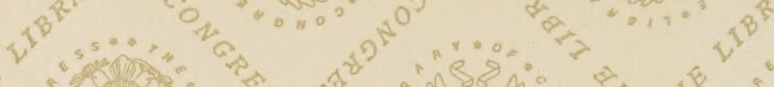

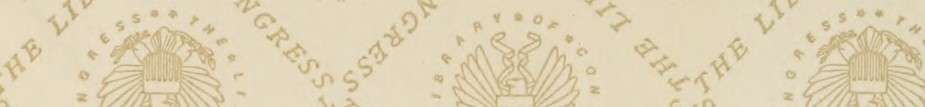

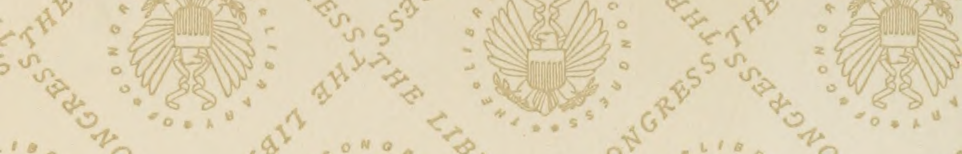

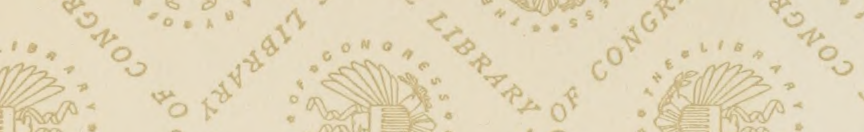

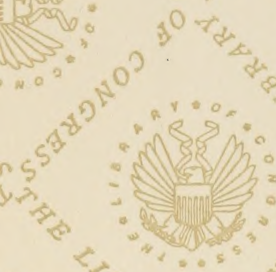

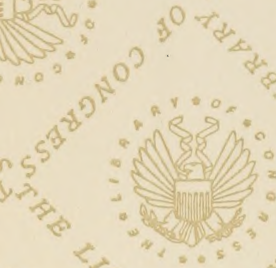

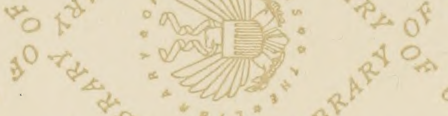

$\therefore 81030$.

एक 80

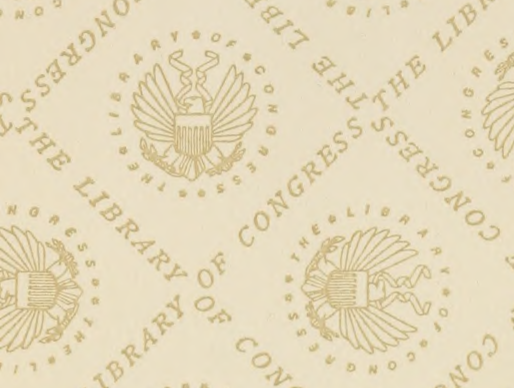

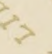

4.

$0^{2}$

${ }_{2} \mathrm{O} / \mathrm{T}_{2}$

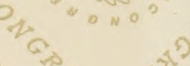

$r=0$

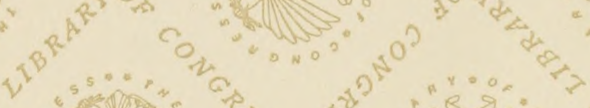

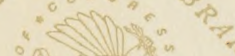
$2 i_{3}={ }^{10}$
20
$4 x^{2}$
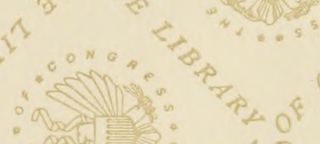
${ }_{3} \mathrm{O} \times$
$\sin _{3} \log ^{\circ}=$

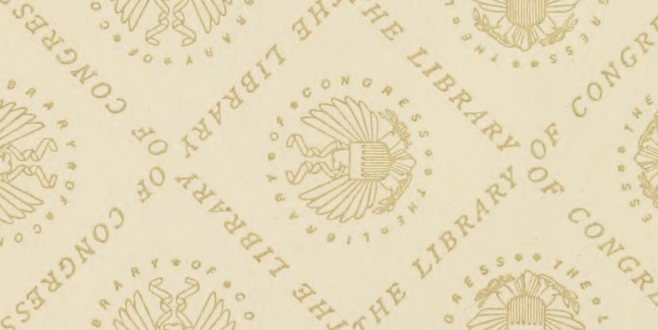

and

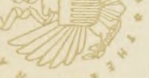





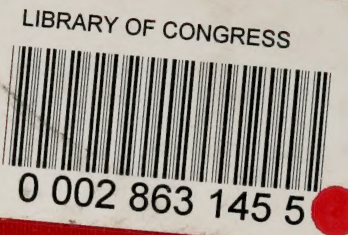

